\title{
Changes in fire intensity have carry-over effects on plant responses after the next fire in southern California chaparral
}

\author{
José M. Moreno, Iván Torres, Belén Luna, Walter C. Oechel \& Jon E. Keeley
}

\author{
Keywords \\ Adenostoma; Ceanothus; Fire cycle; Fire \\ regime; Fire season; Fire severity; Post-fire \\ recruitment; Seeder

\section{Nomenclature} \\ Munz (1974) \\ Received 6 November 2011 \\ Accepted 15 July 2012 \\ Co-ordinating Editor: Kerry Woods
}

\author{
Moreno, J.M. (corresponding author, josem. \\ moreno@uclm.es), Torres, I. (ivan. \\ torres@uclm.es) \& Luna, B. (belen.luna@uclm. \\ es): Department of Environmental Sciences, \\ Universidad de Castilla-La Mancha, Toledo, \\ 45071, Spain \\ Oechel, w.C. (oechel@sunstroke.sdsu.edu): \\ Global Change Research Group and \\ Department of Biology, San Diego State \\ University, San Diego, CA, 92182, USA \\ Oechel, W.C.: CRI Fondazione Edmund Mach, \\ San Michele all'Adige (TN), 38010, Italy \\ Keeley, J.E. (jon_keeley@usgs.gov): U.S. \\ Geological Survey, Western Ecological \\ Research Center, Sequoia National Park, Three \\ Rivers, CA, 93271, USA \\ Keeley, J.E.: Department of Ecology \& \\ Evolutionary Biology, University of California, \\ Los Angeles, CA, 90095, USA
}

\begin{abstract}
Question: Do variations in fire intensity within a stand determine changes in fire intensity and plant demographics in a subsequent fire?

Location: San Diego (CA, USA); chaparral dominated by Adenostoma fasciculatum (resprouter) and Ceanothus greggii (seeder).

Methods: In 2003, a wildfire burned a young (16-yr-old) stand containing a set of experimental plots burned in 1987 with various levels of fire intensity. In 2004, all the 1987 plots were sampled for Adenostoma survival and the recruitment of both species. Similar measures were carried out in the adjacent old (75yr) stand. Fire intensity in 2003 was estimated by a surrogate fire severity measure [minimum diameter of burned branches (branch diameter)].

Results: In the young stand, branch diameter in 2003 was similar to the control plots in 1987, but lower than in the old stand. Fire intensity in 1987 did not significantly affect branch diameter in 2003. Survival of Adenostoma in the young stand was very low, much lower than after the 1987 burn and that in the old stand. Fire intensity in 1987 did not affect Adenostoma survival. Recruitment in Adenostoma increased, and in Ceanothus decreased, with increased fire intensity in 1987.
\end{abstract}

Conclusions: We demonstrate that there is a carry-over effect of fire intensity across a whole fire cycle on plant recruitment of the two dominant species. The 2003 fire partially reversed the relative effects on recruitment caused by elevated fire intensity in 1987. Arguably, this effect was driven by the contrasted relationships of the two species to fire intensity. Adenostoma survival in the young stand was much lower in 2003 than in 1987, despite similar branch diameter, and was also lower than in the old stand, despite higher branch diameter in this case. The causes of such mortality are unknown.

\section{Introduction}

The energy liberated through combustion during a wildfire is highly variable in space and time. As a fire spreads, fire-line intensity and spread rate will change across the landscape due to variations in fuel quantity and quality, wind and topography (Rothermel 1972). Furthermore, for any given place, similar changes can occur across seasons and years, because of variations in weather, climate and fuel as vegetation develops with time (Rothermel \& Philpot 1973). Therefore, variations in the degree of heating to which plants may be exposed during fire are common within a fire (Odion $\&$ Davis
2000) and across fires (Hodgkinson 1991; Knapp \& Keeley 2006). In general, as heating at the soil surface increases, plant mortality, including seeds, increases, and changes in species composition, dominance and spatial distribution may follow, as shown by numerous studies across many world ecosystems (Segura et al. 1998; Morrison 2002; Govender et al. 2006; Knox \& Clarke 2006; Penman \& Towerton 2008), including California chaparral (Moreno \& Oechel 1991b, 1992, 1993; Rice 1993; Tyler 1996; Odion \& Davis 2000; Keeley et al. 2005, 2008).

Nevertheless, given the varying sensitivity of plants to heating in space and time (Wright 1970; Kauffman \& 
Martin 1991; Drewa et al. 2002; Le Fer \& Parker 2005), and the high variability in fire behaviour characteristics and associated heating across scales, from the landscape (Turner et al. 1994) to a few meters (Odion \& Davis 2000) or lower (Hiers et al. 2009), anticipating the effects of fire intensity is complicated (Keeley 2009). This topic continues to be a research priority.

An important limitation in our understanding of the role of varying soil surface heating during fires on plant responses in crown fire ecosystems, such as chaparral and similar shrubland ecosystems, throughout the world is that most studies to date are restricted to the first few years after fire. Long-term studies are uncommon and, more importantly, few studies have investigated the effects across a whole fire cycle. Long-term studies are particularly relevant in systems like chaparral, in which recruitment is largely dependent on fire, there being no significant recruitment in the period between fires (Keeley 1992). Hence, the individuals that establish immediately after fire are the ones that contribute to recovery of the community (Hilbert \& Larigauderie 1990). Recruitment success, however, can be affected by characteristics of the fire. In particular, high soil surface heating can cause reduced regeneration after fire, a change in the dominant species or alterations in the spatial patterns, which could modify biomass accretion and patterns through time and potentially affect fire behaviour in a subsequent fire (Riggan et al. 1988; Odion \& Davis 2000; Hiers et al. 2009).

The use of remote sensing has permitted quantifying how fire severity may be affected by severity of the previous fire (Thompson et al. 2007). While this approach is promising, it also has limitations for understanding the impacts on plant populations since, by relying on wildfires, studies will rarely have detailed information on plant populations across the two fires. Furthermore, fire severity metrics obtained from remote sensing can be too coarse, even for forest ecosystems (French et al. 2008). Moreover, application to shrubland vegetation subject to high-intensity crown fires that kill all above-ground biomass can be problematic (Stow et al. 2007). Indeed, no such study is available for shrubland ecosystems such as chaparral or other Mediterranean-type shrublands.

Nowadays, a main concern for managers is to identify areas of high risk of vegetation regeneration failure due to high fire intensity. To this end, surveys are regularly conducted after fire to identify such areas at risk, which are usually based on fire severity metrics (i.e., surrogates of fire intensity; Keeley 2009). It is then important to understand not only the short-term effects of variations in fire intensity but the longer-term effects, including those across a fire cycle. We need to answer questions such as, to what extent does previous fire intensity alter subsequent fire intensity? That is, is there a carry-over effect of this fire characteristic onto the next fire? If so, for how long does this effect persist? Additionally, will plant demographics vary as a function of previous fire intensity after subsequent burning? Answering these questions would permit better assessment of the role of varying heating on plants and, ultimately, on ecosystem responses.

This paper reports a unique experiment made possible when the southern California Coyote Fire burned in the summer of 2003 through a Ceanothus-Adenostoma chaparral stand containing experimental plots that had been experimentally burned in 1987. In 1987, fuel load had been manipulated before burning to produce different levels of fire intensity in order to determine their effects on the demography of the dominant species in this vegetation (Moreno \& Oechel 1991a,b, 1993).

The experiment that we now report evaluates the carry-over effects of variation in fire intensity in the 1987 fire on the next fire in 2003, 16 yr later. We specifically tested whether the experimentally produced changes in fire intensity in 1987 affected fire intensity surrogates in 2003. Additionally, we tested whether differences in fire intensity in 1987 affected plant survival and seedling recruitment of the two dominant plant species.

Based on the results obtained in the 1987 experiment, we hypothesized the following: plots burned with higher fire intensity in 1987 would burn with lower fire intensity in 2003. The reasoning behind this is that, as fire intensity increased in the 1987 burns, Adenostoma survival decreased (Moreno \& Oechel 1991a), and individuals that resprouted did so later, produced fewer resprouts and grew less during the first few years (Moreno $\delta$ Oechel 1994). Since this is the dominant species, and contributes the largest portion of the biomass of the system, that would have resulted in lower biomass accumulation during the $16 \mathrm{yr}$ after fire and lower fire intensity in the 2003 fire. We further expected that the reduced fire intensity during the 2003 fire in the high fire intensity plots of 1987 would result in higher survival of Adenostoma after 2003. Additionally, seedling recruitment of Adenostoma would be higher the higher the fire intensity in 1987, while the reverse would be anticipated for Ceanothus. This would be due to the contrasted relationships of these two species to fire intensity in 1987 (Moreno \& Oechel 1991b).

\section{Methods}

\section{Study site and fire characteristics}

The study was carried out at the Sky Oaks Biological Field Station $\left(33^{\circ} 21^{\prime} \mathrm{N}, 116^{\circ} 34^{\prime} \mathrm{W}\right.$; $1385 \mathrm{~m}$ a.s.l.), San Diego County, California, USA. The vegetation of the south-facing slopes is composed of a chaparral 
dominated by Adenostoma fasciculatum H. and A. (Rosaceae) and Ceanothus greggii Gray (Rhamnaceae). The climate is mediterranean, with cool wet winters and warm dry summers; mean annual precipitation is $419 \mathrm{~mm}$, mean January temperature is $9.6{ }^{\circ} \mathrm{C}$ and mean July temperature is $25.4{ }^{\circ} \mathrm{C}$ (Oak Grove Remote Automatic Weather Station).

Most of the field station facilities and adjacent land were burned on 17 July 2003, by a 9000-ha wildfire started by lightning (the Coyote Fire, California Department of Forestry $\&$ Fire Protection). The burned area included a set of experimental plots burned in 1987, which in 2003 comprised a 16-yr-old chaparral, plus the surrounding old stand, which at this time was 75 yr old.

The exact time when the experimental plots burned is unknown. Therefore, we used a range of meteorological and fuel-moisture conditions comprising low (low air relative humidity and wind) and high (high air relative humidity and wind) conditions during 17 July 2003, to calculate the main fire characteristics using Behave Plus 4.0 (Andrews et al. 2008). Fuel loads were calculated based on the equations provided by Black (1987) for 16-yr-old chaparral. Fuel fractions were assigned using the proportions given by Weise \& Regelbrugge (1997) for young $A$. fasciculatum (chamise) (SCAL17) fuel model. The remaining fuel model parameters remained unchanged from the chaparral NFFL 4 model. Weather conditions during the day of burning were taken from Oak Grove RAWS (Western Regional Climate Center: http://www.wrcc.dri. edu/), located $16 \mathrm{~km}$ away from Sky Oaks Field Station. The 10-h dead fuel moisture ranged between 3.6\% and $5.1 \%$. The moisture of the rest of the fuel fractions was adjusted using Behave Plus 4.0. Mean wind speed was $0.6 \mathrm{~m} \cdot \mathrm{s}^{-1}$ and mean maximum wind speed was $3.6 \mathrm{~m} \cdot \mathrm{s}^{-1}$. These resulted in estimated fire-line intensities of 420 $5247 \mathrm{KW} \cdot \mathrm{m}^{-1}$, flame lengths of 2-4 m, and flame depths of $1.1-6.5 \mathrm{~m}$, for mean wind and maximum moisture conditions or mean gust wind and minimum moisture conditions, respectively.

\section{Experimental design}

The 1987 plots were placed in an area of ca. 2 ha, in a stand that had not burned since 1929 (59-yr-old stand). Within this area, eight blocks, each with five $5 \mathrm{~m} \times 5 \mathrm{~m}$ plots were established. Each plot within a block was randomly assigned one of five different treatments: control fuel load (no changes in fuel load, three plots), high fuel load (addition of $4 \mathrm{~kg} \cdot \mathrm{m}^{-2}$ of brush, one plot) and very high fuel load (addition of $8 \mathrm{~kg} \cdot \mathrm{m}^{-2}$ of brush, one plot). These fuel manipulations produced three different levels of fire intensity, as attested by the amount of water evaporated from containers during the fire and by measures of temperature at the soil surface or of heat penetration into the soil. From now on, these treatments will be referred to as control (CO), high fire intensity (HI) and very high fire intensity (VHI). In addition, two of the three control plots per block (burned but with no fuel added) received after fire additional amounts of ash and char to simulate the levels falling onto the high and very high fire intensity treatments. This additional ash and char had no effect on plant responses after fire in 1987, and so these plots were used as additional control plots. For further details on the experimental design and results of the 1987 experiment see Moreno \& Oechel (1989, 1991a,b, 1993).

\section{Field sampling}

In October 2004, the 1987 experimental plots (young, 16-yr-old stand) were located and marked for measurements. As in the 1987 experiments, measurements in all plots were taken in the inner $4 \mathrm{~m} \times 4 \mathrm{~m}$ quadrat to reduce the edge effects of the experimental burning. In addition, eight plots of similar size were located in the adjacent old stand, which in 2003 was 75 yr old; similar measurements were carried out on them. Because the 2003 fire was a wildfire, no direct measures of fire intensity were possible; intensity was estimated by using as a fire severity metric post-fire measurement of the minimum diameter of burned branches (branch diameter from now on) in Adenostoma skeletons (Moreno \& Oechel 1989). In each plot, ten plants were selected at random and up to a maximum of 15 randomly selected branches were measured, from which a mean branch diameter per plot was calculated.

Brach diameter was found to be highly correlated $\left(r^{2}=0.90\right)$ with water loss from containers in the 1987 experiment (Moreno \& Oechel 1989), a measure that reflected very well the heat penetration into the soil (e.g., depth of melting of a $62{ }^{\circ} \mathrm{C}$ temperature-sensitive paint, $r^{2}=0.70 ;$ Moreno \& Oechel 1991b). In addition, branch diameter was highly correlated with time-temperature residence during fire (i.e., time above $150{ }^{\circ} \mathrm{C}, r^{2}=0.62$; Pérez \& Moreno 1998). Therefore, branch diameter is a good surrogate for fire intensity (sensu Keeley 2009). For consistency, and to avoid mixing terminology, when comparing the two fires we will mainly refer to fire intensity throughout, even though this was based on various measures of temperatures or heat release in the 1987 fires, and on minimum diameter of the burned branches in 2003.

All Adenostoma plants within each plot were located and their lignotubers measured following the procedures used in Moreno \& Oechel (1989). We measured the length of both the longest and shortest axis of a lignotuber and used the product of the two lengths as an index of size. All 
lignotubers were assumed to have been alive prior to fire, with the exception of those that showed evident signs of rotting. Only lignotubers with green shoots were considered to have survived the fire; those that produced no new shoots or had produced shoots but were dead by the time of sampling were considered not to have survived the fire. The percentage of surviving lignotuber area per plot was calculated by dividing the sum of the areas of the lignotubers of all surviving plants by the sum of the lignotuber areas of all Adenostoma plants in each plot considered alive before fire. Finally, a count of all seedlings of the two dominant species (Adenostoma and Ceanothus) within each plot provided a measure of the level of recruitment from germination after fire.

\section{Statistical analyses}

The effects of the fire intensity treatments in 1987 on intensity (based on its surrogate branch diameter) of the 2003 fire were tested using a randomized complete-block ANOVA, following the original experimental design in 1987 (Moreno \& Oechel 1991b, 1993). Planned comparisons among treatment means (fire intensity in 1987) were carried out by defining two sets of a priori contrasts: (1) control fire intensity (CO) vs changed fire intensity (HI and VHI plots); and (2) high fire intensity (HI) vs very high fire intensity (VHI). The percentage of lignotuber area index surviving the 2003 fire was tested using the randomized complete-block ANOVA described above. Differences in survival of size index classes of Adenostoma after the 2003 fire in relation to 1987 fire intensity treatments and among the two stands (young, old) were analysed with two-sample Kolmogorov-Smirnov tests. Further, the percentage of lignotuber area index surviving after the 2003 fire in both stands was related to the fire intensity surrogate (branch diameter) in 2003 by means of least squares regression. The effect of the 1987 fire intensity treatments on Adenostoma and Ceanothus seedling recruitment (seedling density, No. $\mathrm{m}^{-2}$ ) was tested using the ANOVA model mentioned above. Finally, seedling density of both species was related to branch diameter by least squares regression. Data were transformed prior to analysis when required to ensure normality (percentage lignotuber area index to arcsine, and seedling density in Ceanothus to log).

\section{Results}

Branch diameter (mean \pm SE) per plot in the young stand (all 1987 plots combined) after the 2003 fire was $7.4 \pm 0.2 \mathrm{~mm}$, similar to the control plots in 1987 (7.2 $\pm 0.5 \mathrm{~mm}$; Moreno \& Oechel 1989), and much lower than in the adjacent old stand $(15.4 \pm 0.8 \mathrm{~mm})$. Fire intensity treatments in 1987 did not significantly affect branch diameter in $2003\left(F_{2,34}=2.981, \quad P=0.064\right.$; Fig. 1).

Adenostoma adult plant density in the young stand before the 2003 fire was lower the higher the fire intensity treatment in 1987, which reflects the impacts of the fire intensity experiments in 1987. These effects were particularly visible in the reduced number of small size index individuals as fire intensity increased in 1987 (Table 1, Fig. 2a). Survival of Adenostoma adult individuals after the 2003 fire was lower (33.6\%, all plots combined) in the young stand than in the old stand (55.4\%; Table 1). Survival increased with lignotuber size index (Fig. 3), resulting in a reduced frequency of low size index individuals (Fig. 2b). There were no statistically significant differences in the size classes of surviving adult Adenostoma plants among plots that burned in 1987 with different fire intensity (K-S two-sample test between $\mathrm{CO}$ and $\mathrm{HI}+\mathrm{VHI}: Z=0.588$, $P=0.859 ; \quad K-S$ between $\mathrm{HI}$ and VHI: $Z=1.177$, $P=0.125)$. Differences in the size classes of surviving Adenostoma plants among the control and old stand were significant (K-S two-sample test between $\mathrm{CO}$ and old stand: $Z=1.569 ; P=0.015$; Fig. 3 ).

Survival on a per lignotuber area index basis after the 2003 fire (\% lignotuber area index per plot surviving fire) was higher in the old stand $(75 \pm 5 \%)$ than in the young stand ( $41 \pm 4 \%$, all treatments combined). Fire intensity in 1987 did not significantly affect the percentage lignotuber area index surviving in $2003\left(F_{2,34}=2.457, P=0.101\right.$;

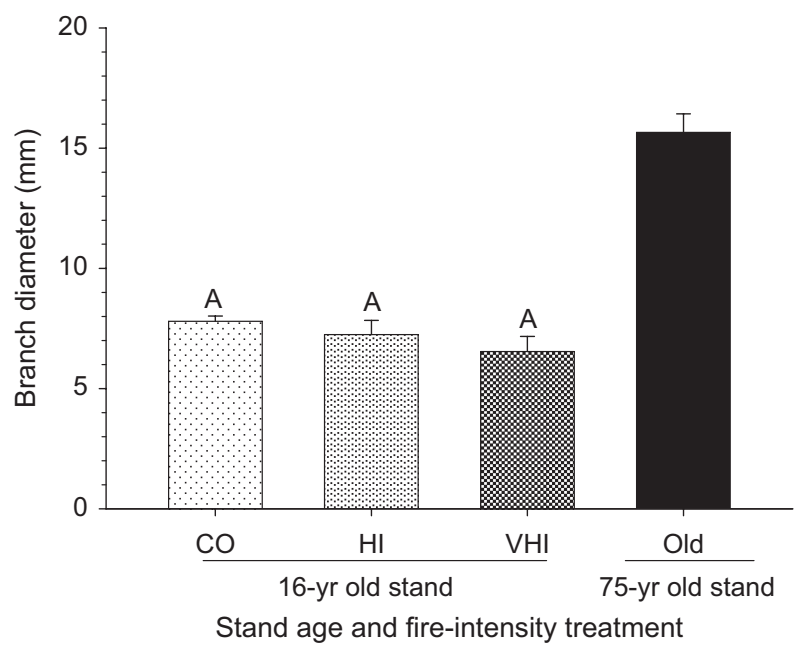

Fig. 1. Mean minimum diameter of burned branches (branch diameter, $\mathrm{mm}$ ) per plot, a surrogate measure of fire intensity, for plots burned in 2003 after having been burned experimentally in 1987 (young stand, 16 yr old) at control (CO), high (HI) or very high (VHI) fire intensity (see Methods) or by a wildfire in 1928 (old stand, $75 \mathrm{yr}$ old) at the Sky Oaks Biological Station in San Diego, CA. Letters above the bars indicate the result of ANOVA for random blocks $\left(F_{2,34}=2.981, P=0.064\right)$. For treatments of the 1987 experimental fire, see Methods and Moreno and Oechel (1991b). 
Table 1. Mean ( \pm SE) Adenostoma fasciculatum adult plant density (No. individuals per $4 \mathrm{~m} \times 4 \mathrm{~m}$ plot) before and after the 2003 fire and survival $1 \mathrm{yr}$ after fire in the young stand (1987 treated plots: control, high and very high fire intensity) and in the old stand.

\begin{tabular}{|c|c|c|c|c|c|c|}
\hline & \multicolumn{2}{|c|}{$\begin{array}{l}\text { Pre-fire } \\
\text { density }\end{array}$} & \multicolumn{2}{|c|}{$\begin{array}{l}\text { Post-fire } \\
\text { density }\end{array}$} & \multicolumn{2}{|c|}{ Survival (\%) } \\
\hline & Mean & SE & Mean & SE & Mean & SE \\
\hline \multicolumn{7}{|l|}{ Young stand } \\
\hline Control intensity & 27.0 & 2.3 & 8.5 & 1.2 & 29.3 & 3.3 \\
\hline High intensity & 21.9 & 3.3 & 7.5 & 1.7 & 33.4 & 5.1 \\
\hline Very high intensity & 13.1 & 2.0 & 5.9 & 1.5 & 42.2 & 7.1 \\
\hline Old stand & 23.0 & 2.6 & 12.8 & 1.6 & 55.4 & 2.4 \\
\hline
\end{tabular}
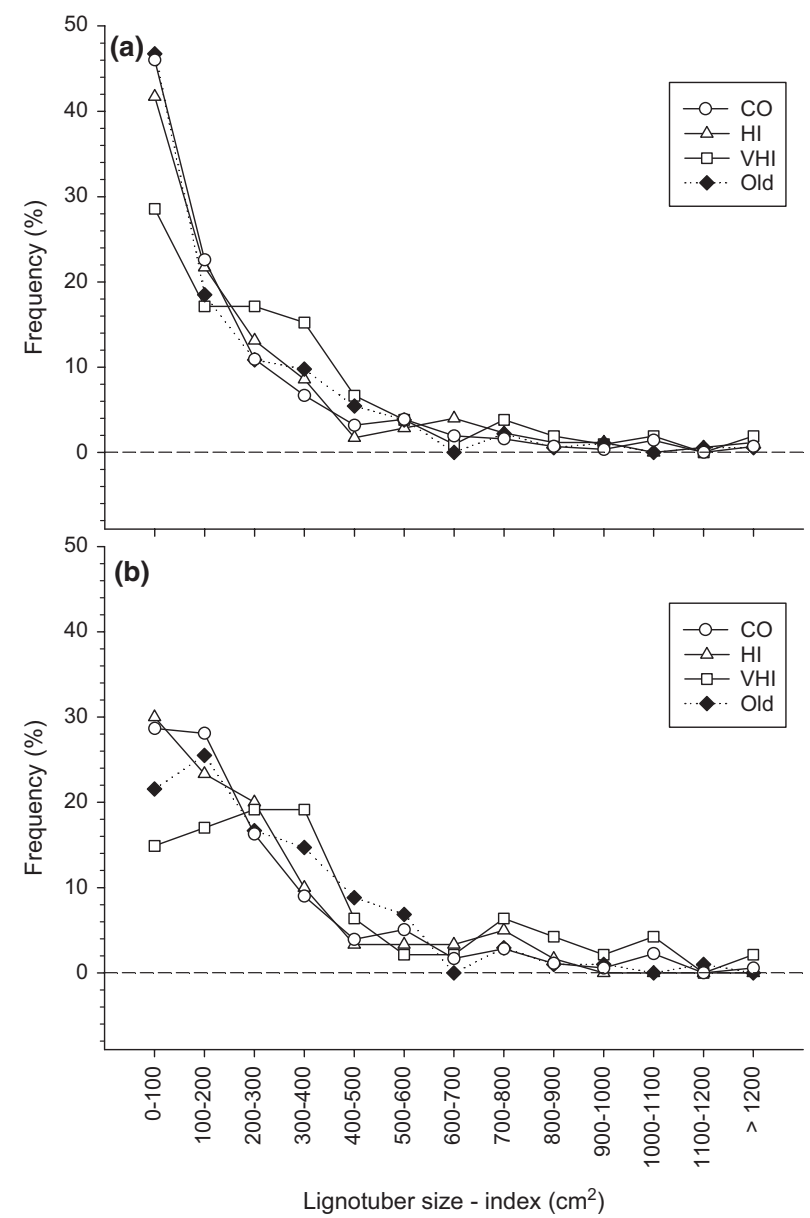

Fig. 2. Lignotuber size index frequency distribution of Adenostoma fasciculatum plants (a) before the 2003 fire, (b) after the 2003 fire, in plots burned experimentally in 1987 with a different fire intensity (CO, HI, VHI) (young stand, $16 \mathrm{yr}$ old) or by a wildfire in 1928 (old stand, $75 \mathrm{yr}$ old), at the Sky Oaks Biological Station in San Diego, CA.

Fig. 4). In the young stand, branch diameter in 2003 was a good predictor of the percentage of lignotuber area index surviving, which statistically significantly decreased as

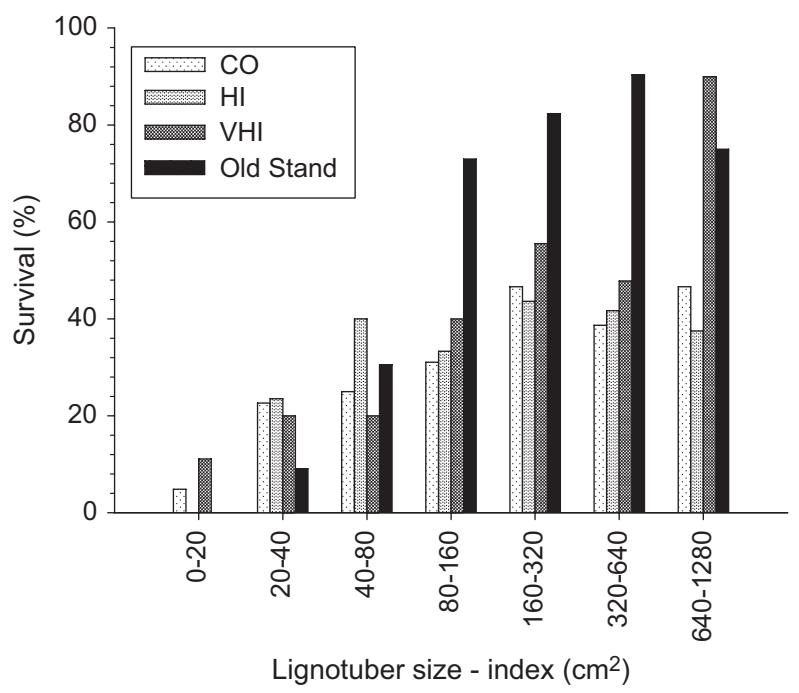

Fig. 3. Survival of adult plants of Adenostoma fasciculatum $1 \mathrm{yr}$ after the 2003 fire as a function of lignotuber size index for the plots burned experimentally in 1987 (young stand, $16 \mathrm{yr}$ old) at control (CO), high (HI) or very high (VHI) fire intensity or by a wildfire in 1928 (old stand, $75 \mathrm{yr}$ old) at the Sky Oaks Biological Station in San Diego, CA. Kolmogorov-Smirnov two-sample tests: CO vs $\mathrm{HI}+\mathrm{VHI} \quad(Z=0.588$, $P=0.859) ; \mathrm{HI}$ vs VHI $(Z=0.588 ; P=0.859)$; $C O$ vs old stand $(Z=1.569$; $P=0.015)$.

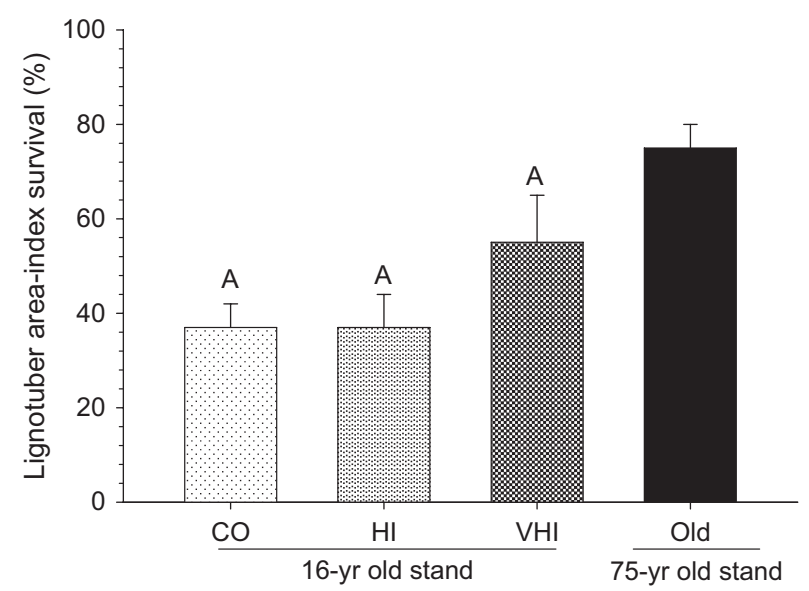

Stand age and fire-intensity treatment

Fig. 4. Percentage of surviving Adenostoma lignotuber area index in plots burned in 2003 after having been burned experimentally in 1987 (young stand, $16 \mathrm{yr}$ old) at control (CO), high (HI) or very high (VHI) fire intensity (see Methods) or by a wildfire in 1928 (old stand, 75 yr old) at the Sky Oaks Biological Station in San Diego, CA. Letters above the bars indicate the result of ANOVA for random blocks $\left(F_{2,34}=2.457, P=0.101\right)$. For treatments of the 1987 experimental fire see Methods and Moreno and Oechel (1991b).

branch diameter increased $\left(m=-0.068, \quad r^{2}=0.14\right.$, $P=0.025)$. This relationship was not significant in the old stand $\left(m=0.047, r^{2}=0.26, P=0.198\right)$. 
Adenostoma seedling density (No. $\mathrm{m}^{-2}$ ) $1 \mathrm{yr}$ after fire was similar in the control plots of the young stand and in the old stand, and lower in both types of plots than in the increased fire intensity plots in the 1987 fire. In the young stand, seedling density of Adenostoma significantly increased as fire intensity increased in $1987\left(F_{2,34}=12.39\right.$, $P<0.001$; Fig. 5a). Ceanothus seedling density $1 \mathrm{yr}$ after fire was much higher in the old stand than in the young stand. In the young stand, Ceanothus seedling density was higher in the control plots than in the increased fire intensity plots in $1987\left(F_{2,34}=6.66, P=0.004\right.$; Fig. 5b).

In the young stand, seedling density of Adenostoma was negatively related to branch diameter in 2003 ( $m=-0.45$, $r^{2}=0.28, P=0.001$; Fig. 6a); Ceanothus seedling density was not related to branch diameter in $2003(m=0.2572$, $r^{2}=0.02, P=0.410$; Fig. $\left.6 \mathrm{~b}\right)$. In the old stand, neither
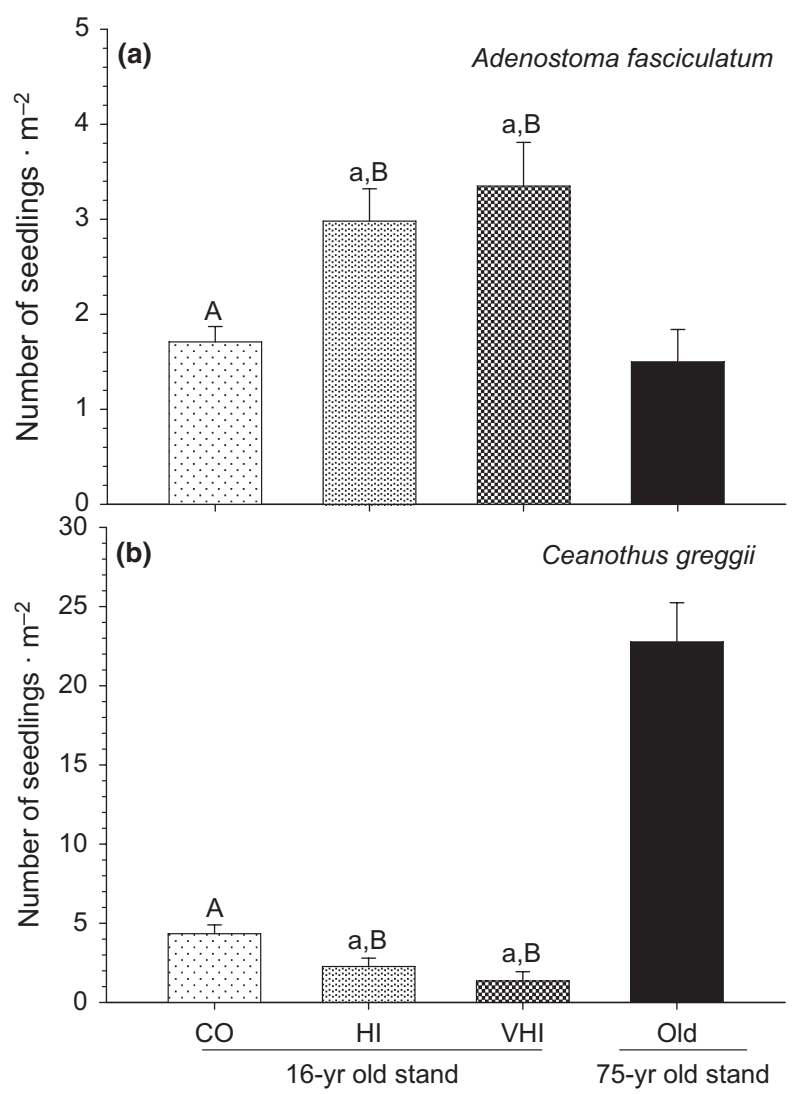

Stand age and fire-intensity treatment

Fig. 5. Seedling density (No. $\mathrm{m}^{-2}$ ) of (a) Adenostoma fasciculatum, and (b) Ceanothus greggii, $1 \mathrm{yr}$ after the 2003 fire in the plots burned experimentally in 1987 (young stand, 16 yr old) at control (CO), high (HI) or very high (VHI) fire intensity (see Methods) or remained unburned since 1928 (old stand, 75 yr old) at the Sky Oaks Biological Station in San Diego, CA. Letters above the bars indicate the result of a priori contrasts based on ANOVA for random blocks (Adenostoma: $F_{2,34}=12.39, P<0.001$; Ceanothus: $\left.F_{2,34}=6.66, P=0.004\right)$. Different letters for a given contrast indicate statistically significant differences $(P \leq 0.05)$.

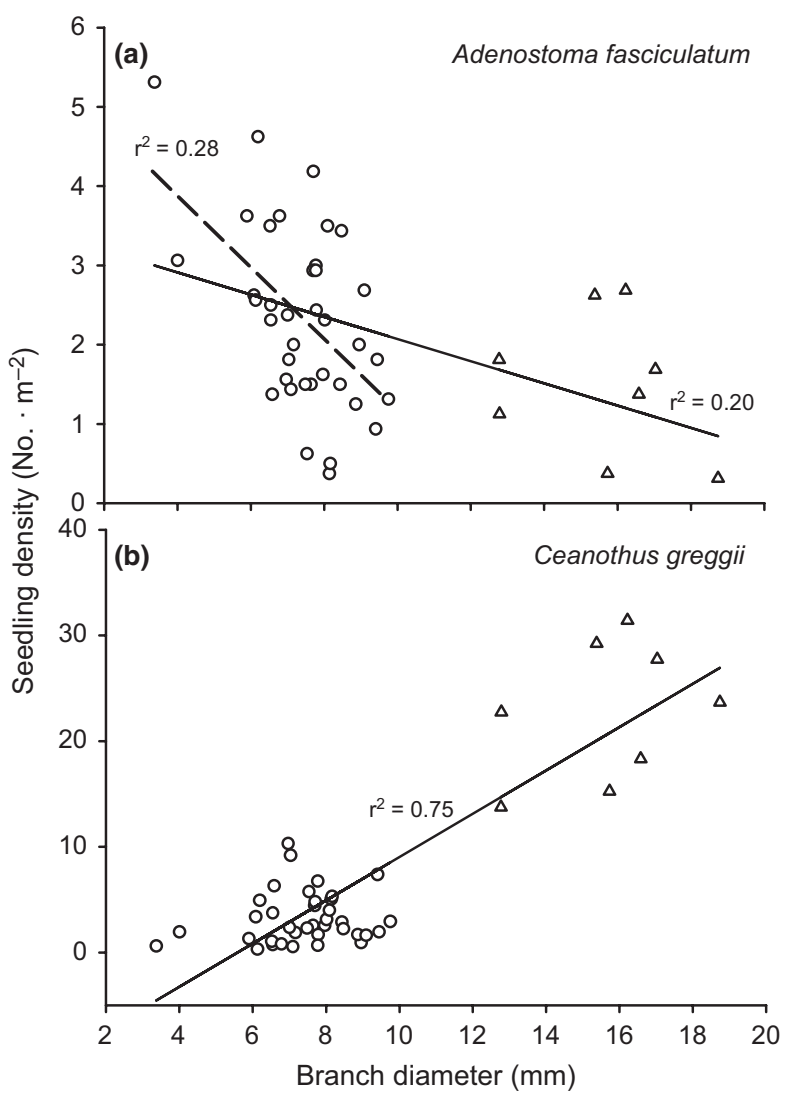

Fig. 6. Relationships between the density (No. $\mathrm{m}^{-2}$ ) of (a) Adenostoma fasciculatum, and (b) Ceanothus greggii, $1 \mathrm{yr}$ after fire, and branch diameter $(\mathrm{mm})$ (a surrogate measure of fire intensity) for the plots burned experimentally in 1987 (young stand, 16 yr old; circles) and in the adjacent old stand (75 yr old; triangles) at the Sky Oaks Biological Station in San Diego, CA. Only significant relationships are shown: A. fasciculatum $\left(r^{2}=0.28, P=0.001\right.$ for the young stand; $r^{2}=0.20, P=0.002$ for both stands combined); C. greggii $\left(r^{2}=0.75, P<0.001\right.$ for both stands combined).

Adenostoma nor Ceanothus seedling density were significantly related to branch diameter in $2003(m=-0.105$, $r^{2}=0.06, \quad P=0.574 ; \quad m=1.181, \quad r^{2}=0.13, \quad P=0.375$, respectively). Similar analysis including both stands together resulted in significant relationships for Adenostoma $\left(m=-0.144 ; \quad r^{2}=0.20, \quad P=0.002\right) \quad$ and Ceanothus $\left(m=2.0511, r^{2}=0.75, P<0.001\right.$; Fig. 6$)$.

\section{Discussion}

Variation across plots in fire intensity created by the experimental fires of 1987 did not significantly affect fire intensity surrogate (branch diameter) when these plots were burned again by a wildfire (Fig. 1). Despite large differences in the fire intensity and impact produced during the 1987 experimental burning, 16 yr later these differences were not sufficient to significantly affect fire intensity in 
the various plots. Several factors could have contributed to this result. Assuming that conditions were stable while the plots were burning, changes in fire intensity were expected in 2003 due to differences in biomass among plots. Indeed, during the first years after the 1987 fire, biomass was lower in the plots burned with high fire intensity than in the control ones (Moreno \& Oechel 1994). However, $16 \mathrm{yr}$ may have been sufficient to equalize biomass in the various plots, independent of how severely they had burned. This could be explained by the fact that Adenostoma is dominant in the stand, and that the mortality caused by increasing fire intensity in 1987 was concentrated in the smaller size individuals, whose contribution to the overall biomass of the stand would have been small as the years passed. That is, a high impact at the demographic level does not necessarily translate into a similar impact for other ecosystems properties (Riggan et al. 1988).

An additional explanation is that the size of the plots was too small to affect fire behaviour and intensity in a way detectable with our branch diameter metric. Fire intensity can vary at very small scales $(>1 \mathrm{~m})$ due to differences in fuel load (Davis et al. 1989; Hiers et al. 2009) or canopy structure (Schwilk 2003). Heating patterns at scales of 4-5 m can emerge in relation to pre-fire patterns of canopy configuration (Odion \& Davis 2000). Yet, it is possible that the fire intensity recorded in the plots was influenced by conditions of surrounding areas as well as biomass and its configuration within plots. Any moving fire produces a flame front of variable flame length and flame depth. Modelled flame depths varied from more than $1 \mathrm{~m}$ to several meters, depending on wind and moisture. Flames of this magnitude were probably large enough to produce a combustion environment that could have, in part, overridden the biomass existing within the plots. All surrounding areas of the plots were burned in 1987 at control fire intensity; hence they were expected to have equal or higher biomass than the plots burned with high intensity. While the effect of the neighbouring areas on branch diameter within the plots cannot be estimated with any accuracy, it is possible that larger plot sizes would have revealed significant effects of fire intensity in 1987 on branch diameter and subsequent fire intensity in 2003 (Fig. 1).

Our results show that survival of Adenostoma was not significantly different among plants of various lignotuber size indices across different 1987 fire intensities. Additionally, fire intensity in 1987 did not affect the percentage of surviving lignotuber area of Adenostoma after 2003. Notwithstanding, fire intensity in 2003 was a significant factor in determining the percentage of surviving lignotuber area of Adenostoma in the young stand, which experienced high mortality. No such relationships were found in the old stand. This leads us to conclude that fire intensity can be important for Adenostoma survival, and that variations within a burn can have a significant impact. Yet, the variability across the two burns due to changes in fire intensity in the previous fire was not statistically significant, suggesting that any carry-over effects of the variations in fire intensity in 1987 over Adenostoma survival were short-lived. The unnatural fuel structure created by the treatments in 1987 probably caused variations in fire intensity that were much larger than those that usually occur under normal conditions. If such large variations did not produce a significant carry-over effect, it is unlikely that normal (i.e., smaller, see variability of branch diameter in Fig. 1 for any treatment) variations in fire intensity within a stand in a wildfire will produce significant effects. This means that the carry-over effects of variations in fire intensity on Adenostoma plant survival in a normal fire are probably not very important.

We document that the overall survival of Adenostoma plants was much lower after the 2003 fire than after the 1987 fires. Survival of Adenostoma in the control fire intensity plots of the young stand was low in spite of the low fire intensity recorded. This low survival contrasts with results obtained in the 1987 experimental burns under control fuel load and mild weather conditions typical of early spring. Those burns resulted in low, and similar, fire intensity, unlike the 2003 fire, but resulted in very high survival (above 95\% in most size classes), with mortality restricted to small lignotuber size index individuals (Moreno $\delta$ Oechel 1991a, 1993). The high mortality after the 2003 fire applied to individuals of all sizes. This also contrasts with survival in the old stand, which was higher than in the young stand even though fire intensity as indexed by branch diameter was much higher. Survival in the young stand was lower than in a 24 -yr-old stand (68\% survival), despite similar branch diameter, and even lower than in a 3-yr-old stand (42\% survival) (Keeley \& Brenan 2012). The cause of this much lower survival is unknown but, as discussed above, it was not related to changes in fire intensity in 1987 . Whether the time of burning in a previous fire (early spring in the 1987 fire) affects the survival of Adenostoma with time (for as long as $16 \mathrm{yr}$ ) needs to be investigated.

Observed carry-over effects on seedling recruitment of both Adenostoma and Ceanothus, with higher recruitment of Adenostoma and lower recruitment of Ceanothus, are more relevant if we take into account higher mortality with higher fire intensity among Adenostoma plants in 1987. This pattern may have influenced Adenostoma seed availability 16 yr later. As for Ceanothus, more plants emerged in the high fire intensity plots than in the other two types of plot in 1987. Nevertheless, seed availability may have been influenced by small plot size, which was within the range of the ballistic mechanisms of dispersal from outside the plots (Evans et al. 1987). Hence, seed availability in all 
plots more likely reflected seed production in the control plots, since this is the intensity at which the whole stand burned. The exact cause of this carry-over effect is unknown, but it points to the contrasting sensitivity of two species to fire intensity (see Fig. 6). This finding rests on the assumption that the climate conditions after the fire did not change recruitment among plots burned with different fire intensity in 1987, and is supported by the fact that the year after fire was not at any particular extreme.

The contrasted sensitivity of the two species to fire intensity is further shown by the recruitment levels in the old stand. The Adenostoma seed bank was probably much larger in the old than in the young stand (Zammit \& Zedler 1988), yet its overall recruitment was similar in both stands. The opposite pattern was found for Ceanothus, whose recruitment was much higher in the old stand than in the young one, even though Ceanothus does not accrue seeds in the seed bank with age (Zammit \& Zedler 1988). It is worth noting that branch diameter was a significant factor in recruitment across stands that differed so much in time since the last fire (16 and $75 \mathrm{yr}$ ). In the case of Ceanothus this variable accounted for $75 \%$ of the variance in recruitment across both stands. Comparison with germination obtained after the 1987 burns in the control plots (at that time they were 59-yr-old stands, so not much different to the 75-yr-old stand now), which burned with low intensity, reflect well these contrasting patterns: emergence of Adenostoma was much higher and that of Ceanothus much lower (Moreno \& Oechel 1991b, 1992).

Our study documents that the effects caused by changes in fire intensity on seedling recruitment can be reversed in part in a next fire. Hence, the lower germination of Adenostoma in 1987, caused by increasing fire intensity, resulted in elevated recruitment after the 2003 fire. The relationship was the reverse for Ceanothus. This, to our knowledge, is the first time that a compensatory mechanism for the effects of a characteristic of fire, such as fire intensity, on plant populations is documented. This response appeared to be related to the contrasting sensitivity of these two species to fire intensity (see Figs. 5,6). Since changes in fire intensity are probably related to growth and biomass accumulation after fire, the period during which this mechanism operates was probably at the limit, since, as discussed earlier, there were no carry-over effects on fire intensity. This is important since, even though the probability of burning for young stands is low (Keeley $\&$ Fotheringham 2003), recurrent fires beyond the first few years following very severe fires would not favour the more heat-tolerant species (Ceanothus), but would tend to restore the losses caused by such fires by increasing recruitment of Adenostoma. Nevertheless, considering that some of the treatments implemented in 1987 produced variations in fire intensity above normal, no large differences in recruitment are to be expected across a fire cycle due to fire intensity, even if fires occurred at relatively short intervals beyond a few years (Zedler et al. 1983; Keeley \& Brenan 2012). Changes in fire intensity could affect other vegetation components, like herbs, including non-native species, which have also been shown to be sensitive to such changes (Moreno \& Oechel 1991b; Keeley et al. 2008; Keeley \& Brenan 2012), but these were not investigated here.

\section{Acknowledgements}

We thank Janet Franklin, Heather Karnes Schmalbach and Linnea Spears-Lebrun for their help. We are thankful to Glenn Buskirk and SDSU Field Stations Program for logistic support during fieldwork. Dr. Kerry Woods and two anonymous reviewers made most valuable comments. This research was supported by a FPU grant from the Spanish Ministry of Education and Science to I.T. (AP 2003 - 1440). Writing benefited from the FUME project (ENV-2009-GA243888).

\section{References}

Andrews, P.L., Bevins, C.D. \& Seli, R.C. 2008. BehavePlus fire modeling system, version 4.0: user's guide. [General Technical Report RMRS-GTR-106]. Department of Agriculture, Forest Service. Rocky Mountain Research Station, US.

Black, C.H. 1987. Biomass, nitrogen, and phosphorus accumulation over a southern California fire cycle chronosequence. In: Tenhunen, J.D., Catarino, F.M., Lange, O.L. \& Oechel, W.C. (eds.) Plant response to stress: functional analysis in Mediterranean ecosystems. pp. 445-458. Springer, Berlin, DE.

Davis, F.W., Borchert, M.I. \& Odion, D.C. 1989. Establishment of microscale vegetation pattern in maritime chaparral after fire. Vegetatio 84: 53-67.

Drewa, P.B., Platt, W.J. \& Moser, E.B. 2002. Fire effects on resprouting of shrubs in headwaters of southeastern longleaf pine savannas. Ecology 83: 755-767.

Evans, R.A., Biswell, H.H. \& Palmquist, D.E. 1987. Seed dispersal in Ceanothus cuneatus and C. leucodermis in a Sierran oak-woodland savanna. Madroño 34: 283-293.

French, N.H.F., Kasischke, E.S., Hall, R.J., Murphy, K.A., Verbyla, D.L., Hoy, E.E. \& Allen, J.L. 2008. Using Landsat data to assess fire and burn severity in the North American boreal forest region: an overview and summary of results. International Journal of Wildland Fire 17: 443-462.

Govender, N., Trollope, W.S.W. \& Van Wilgen, B.W. 2006. The effect of fire season, fire frequency, rainfall and management on fire intensity in savanna vegetation in South Africa. Journal of Applied Ecology 43: 748-758.

Hiers, J.K., O`Brien, J.J., Mitchell, R.J., Gego, J.M. \& Loudermilk, E.L. 2009. The wildland fuel concept: an approach to characterize fine-scale variation in fuels and fire in 
frequently burned longleaf pine forest. International Journal of Wildland Fire 18: 315-325.

Hilbert, D.W. \& Larigauderie, A. 1990. A modelling approach to the concept of stand senescence in chaparral. Acta Oecologica 11: 181-190.

Hodgkinson, K.C. 1991. Shrub recruitment response to intensity and season of fire in a semi-arid woodland. Journal of Applied Ecology 28: 60-70.

Kauffman, J.B. \& Martin, R.E. 1991. Factors influencing the scarification and germination of three montane Sierra Nevada shrubs. Northwest Science 65: 180-187.

Keeley, J.E. 1992. Recruitment of seedlings and vegetative sprouts in unburned chaparral. Ecology 73: 1194-1208.

Keeley, J.E. 2009. Fire intensity, fire severity and burn severity: a brief review and suggested usage. International Journal of Wildland Fire 18: 116-126.

Keeley, J.E. \& Brenan, T.J. 2012. Fire-driven alien invasion in a fire-adapted ecosystem. Oecologia 169: 1043-1052.

Keeley, J.E. \& Fotheringham, C.J. 2003. Impact of past, present, and future fire regimes on North American Mediterranean shrublands. In: Veblen, T.T., Baker, W.L., Montenegro, G. \& Swetnam, T.W. (eds.) Fire and climatic change in temperate ecosystems of the Western Americas. pp. 218-262. Springer, New York, NY, US.

Keeley, J.E., Fotheringham, C.J. \& Baer-Keeley, M. 2005. Factors affecting plant diversity during post-fire recovery and succession of Mediterranean-climate shrublands in California, USA. Diversity and Distributions 11: 525-537.

Keeley, J.E., Brennan, T. \& Pfaff, A.H. 2008. Fire severity and ecosystem responses following crown fires in California shrublands. Ecological Applications 18: 1530-1546.

Knapp, E.E. \& Keeley, J.E. 2006. Heterogeneity in fire severity within early season and late season prescribed burns in mixed-conifer forest. International Journal of Wildland Fire 15: $37-45$.

Knox, K.J.E. \& Clarke, P.J. 2006. Fire season and intensity affect shrub recruitment in temperate sclerophyllous woodlands. Oecologia 149: 730-739.

Le Fer, D. \& Parker, V.T. 2005. The effect of seasonality of burn on seed germination in chaparral: the role of soil moisture. Madroño 52: 166-174.

Moreno, J.M. \& Oechel, W.C. 1989. A simple method for estimating fire intensity after a burn in California chaparral. Acta Oecologica-Oecologia Plantarum 10: 57-68.

Moreno, J.M. \& Oechel, W.C. 1991a. Fire intensity and herbivory effects on postfire resprouting of Adenostoma fasciculatum in Southern California chaparral. Oecologia 85: 429-433.

Moreno, J.M. \& Oechel, W.C. 1991b. Fire intensity effects on germination of shrubs and herbs in Southern California chaparral. Ecology 72: 1993-2004.

Moreno, J.M. \& Oechel, W.C. 1992. Factors controlling postfire seedling establishment in Southern California chaparral. Oecologia 90: 50-60.
Moreno, J.M. \& Oechel, W.C. 1993. Demography of Adenostoma fasciculatum after fires of different intensities in Southern California chaparral. Oecologia 96: 95-101.

Moreno, J.M. \& Oechel, W.C. 1994. Fire intensity as a determinant factor of postfire plant recovery in southern California chaparral. In: Moreno, J.M. \& Oechel, W.C. (eds.) The role of fire in Mediterranean-type ecosystems. pp. 26-45. Springer, New York, NY, US.

Morrison, D.A. 2002. Effects of fire intensity on plant species composition of sandstone communities in the Sydney region. Austral Ecology 27: 433-441.

Munz, P.A.. 1974. A Flora of Southern California. University of California Press, Berkeley, CA, US.

Odion, D.C. \& Davis, F.W. 2000. Fire, soil heating, and the formation of vegetation patterns in chaparral. Ecological Monographs 70: 149-169.

Penman, T.D. \& Towerton, A.L. 2008. Soil temperatures during autumn prescribed burning: implications for the germination of fire responsive species? International Journal of Wildland Fire 17: 572-578.

Pérez, B. \& Moreno, J.M. 1998. Methods for quantifying fire severity in shrubland-fires. Plant Ecology 139: 91-101.

Rice, S.K. 1993. Vegetation establishment in postfire Adenostoma chaparral in relation to fine-scale pattern in fire intensity and soil nutrients. Journal of Vegetation Science 4: 115-124.

Riggan, P.J., Goode, S., Jacks, P.M. \& Lockwood, R.N. 1988. Interaction of fire community development in chaparral of southern California. Ecological Monographs 58: 155-176.

Rothermel, R.C. 1972. A mathematical model for predicting fire spread in wildland fuels. Research paper INT-1 15, USDA Forest Service, Ogden, UT, US. pp.40.

Rothermel, R.C. \& Philpot, C.W. 1973. Predicting changes in chaparral flammability. Journal of Forestry 71: 640643.

Schwilk, D.W. 2003. Flammability is a niche construction trait: canopy architecture affects fire intensity. The American Naturalist 162: 725-733.

Segura, A.M., Holmgren, M., Anabalon, J.J. \& Fuentes, E.R. 1998. The significance of fire intensity in creating local patchiness in the Chilean matorral. Plant Ecology 139: 259-264.

Stow, D., Petersen, A., Rogan, J. \& Franklin, J. 2007. Mapping burn severity of Mediterranean-type vegetation using satellite multispectral data. Geographic information systems science and remote sensing 44: 1-23.

Thompson, J.R., Spies, T.A. \& Ganio, L.M. 2007. Reburn severity in managed and unmanaged vegetation in a large wildfire. Proceedings of the National Academy of Sciences, USA 104: 10743-10748.

Turner, M., Hargrove, W.W., Gardner, R.H. \& Romme, W.H. 1994. Effects of fire on landscape heterogeneity in Yellowstone National Park, Wyoming. Journal of Vegetation Science 5: 731-742. 
Tyler, C.M. 1996. Relative importance of factors contributing to postfire seedling establishment in maritime chaparral. Ecology 77: 2182-2195.

Weise, D.R. \& Regelbrugge, J. 1997. Recent chaparral fuel modelling efforts. Resource Management: The Fire Element; Newsletter of the California Fuels Committee. U.S.D.A. Forest Service, Pacific Southwest Research Station. Prescribed Fire and Fire Effects Research Unit, Riverside, CA, US.

Wright, H.A. 1970. A method to determine heat caused mortality in bunchgrass. Ecology 51: 582-587.
Zammit, C.A. \& Zedler, P.H. 1988. The influence of dominant shrubs, fire, and time since fire on soil seed banks in mixed chaparral. Vegetatio 75: 175-187.

Zedler, P.H., Gautier, C.R. \& McMaster, G.S. 1983. Vegetation change in response to extreme events: the effect of a short interval between fires in California chaparral and coastal scrub. Ecology 64: 809-818. 